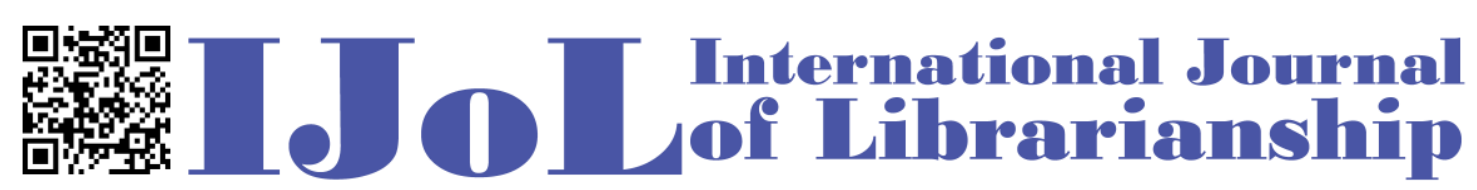

ISSN: 2474-3542 Journal homepage: http://journal.calaijol.org

\title{
Understanding Data Literacy Requirements for Assignments: A Business School Syllabus Study
}

\author{
Meryl Brodsky
}

\begin{abstract}
:
Syllabus studies have been used to inform librarians' work in collection development, instruction and information literacy. Syllabi also provide an opportunity to understand course requirements for data literacy. In this study, syllabi from Eastern Michigan University's College of Business were analyzed to determine which courses require data literacy for the completion of assignments or projects. The author tested several hypotheses to identify where data literacy instruction would be most needed:

1. Data use in online and hybrid class assignments is greater than for in-person class assignments

2. Graduate students have greater data requirements than undergraduate students

3. Different business school disciplines have different data needs (i.e., marketing has more, accounting has less)

Though this was not a scientific study, analyzing syllabi and assignments can reveal both stated and implied data literacy competencies. Surfacing these competencies and making them explicit gives the librarian and the teaching faculty the opportunity to co-design relevant teaching and learning activities. Since data literacy instruction is a new initiative at the Eastern Michigan University Library, the author also used this study to bring attention to this capacity.
\end{abstract}

To cite this article:

Brodsky, M. (2017). Understanding data literacy requirements for assignments: A business school syllabus study. International Journal of Librarianship, 2(1), 3-15. https://doi.org/10.23974/ijol.2017.vol2.1.25

To submit your article to this journal:

Go to http://ojs.calaijol.org/index.php/ijol/about/submissions 


\title{
Understanding Data Literacy Requirements for Assignments: A Business School Syllabus Study
}

\author{
Meryl Brodsky \\ Eastern Michigan University Library, Ypsilanti, MI, USA
}

\begin{abstract}
Syllabus studies have been used to inform librarians' work in collection development, instruction and information literacy. Syllabi also provide an opportunity to understand course requirements for data literacy. In this study, syllabi from Eastern Michigan University's College of Business were analyzed to determine which courses require data literacy for the completion of assignments or projects. The author tested several hypotheses to identify where data literacy instruction would be most needed:

1. Data use in online and hybrid class assignments is greater than for in-person class assignments

2. Graduate students have greater data requirements than undergraduate students

3. Different business school disciplines have different data needs (i.e., marketing has more, accounting has less)

Though this was not a scientific study, analyzing syllabi and assignments can reveal both stated and implied data literacy competencies. Surfacing these competencies and making them explicit gives the librarian and the teaching faculty the opportunity to co-design relevant teaching and learning activities. Since data literacy instruction is a new initiative at the Eastern Michigan University Library, the author also used this study to bring attention to this capacity.
\end{abstract}

Keywords: data literacy, information literacy, library instruction, academic librarians, syllabi

\section{INTRODUCTION}

In a 2016 article from the American Association of Collegiate Schools of Business' (AACSB, the accrediting organization for business schools) online publication, Bized, Bill Hardgrave, Dean of Auburn University's Harbert College of Business wrote "Our industry advisory board members and individual business leaders told us that they were looking for a different set of analytical skills from our students - they wanted students who could gather data, analyze data, and make decisions with data." (Hargrave, 2016) A survey of employers and college students by the Association of American Colleges \& Universities (AACU) agreed with the advisory board. The AACU study identified learning outcomes that employers most valued in college graduates but that recent 
graduates were not prepared to address. These included solving/analyzing complex problems and working with numbers and statistics. (Hart Research Associates, 2015)

Students enrolled in Eastern Michigan University's business programs are required to take an introductory business statistics course. Like most traditional statistics courses, it focuses on performing statistical analysis via hypothesis testing, chi-square tests, and regression analysis. (Bowerman, et al., 2015) The material in that course does not address the employer needs identified by Auburn's Advisory Board and the AACU study.

Dr. Milo Schield, Director for the W. M. Keck Statistical Literacy Project, states that traditional business statistics courses are not relevant to the work of business school graduates. Instead he suggests business students take a class on statistical literacy, a term he uses to describe the critical thinking skills that managers use to make better decisions using numbers. (Schield, 2013) The terminology differs, but relying on the Carlson, et al. (2011) definition of data literacy as "understanding what data mean, including how to read charts appropriately, draw correct conclusions from data and recognize when data are being used in misleading or inappropriate ways," the author argues that data literacy is synonymous with statistical literacy. Hence, there is a real need for data literacy in business school programs, because it is not part of the regular curriculum and employers want graduates with these kinds of analytical skills. This study identifies classes where data literacy instruction would be appropriate.

\section{Background Research: Determining Data Literacy Needs}

Much of initial research that discusses identifying instructional needs related to data refers to data information literacy (DIL). DIL details the lifecycle of data from creation through storage and metadata. DIL includes the production and maintenance of data, which are specialized skills not typically needed by business school graduates (undergraduates and MBA students). Librarians have identified instructional opportunities related to DIL via interviews with faculty and through questions received by library and data services staff. (Carlson et al., 2011). One study used syllabi to determine information and DIL teaching opportunities using a grounded theory approach, which involved understanding the goals of the course, and how each assignment built towards those goals. (Maybee et al., 2015) Curriculum mapping has also been used to uncover DIL opportunities. (Macy and Coates, 2016) Curriculum mapping involves gathering professional standards, academic learning outcomes, course syllabi and assignments to create course goals.

In contrast to DIL, data literacy focuses on the consumption of data. Business school students mainly work with secondary source data, which is consistent with the skills employers are looking for in terms of working with data and statistics. (2013):

Data literacy focuses on the following competencies, as outlined by Prado and Marzal

1. Understanding what data is, and how it affects society

2. Finding and/or obtaining data sources

3. Reading, interpreting and evaluating data

4. Managing data

5. Using data, including ethical uses

There are a few articles in the literature about identifying data literacy instruction opportunities. Identifying data literacy teaching opportunities at universities has been done in 
systematic and unsystematic ways. For example, Hogenboom, Holler Phillips and Hensley (2011) conducted a survey to learn how instructors use data in teaching and the problems they face. Mooney and Silver (2010) reached out to faculty known to use data, based on buying patterns and reference questions from the College of Business.

\section{Syllabus Studies}

A syllabus study is a systematic method that allows librarians to rate syllabi by specific criteria. Syllabus studies have been used for a variety of purposes, ranging from collection assessment to identifying opportunities for information literacy instruction to understanding library use.

The author chose to conduct a syllabus study because the number of syllabus studies that have been conducted in business is small compared to those undertaken more generally or in other disciplines. Only three syllabus studies focus specifically on business programs. In addition, as a relatively new library liaison, a syllabus study would allow the author to become familiar with the courses in the College of Business more quickly than interviewing faculty members, or surveying faculty about course data needs or responding to data-related reference questions.

Dewald (2003) performed a syllabus study to determine how much library use or research was expected of business students at Penn State. She found that on the whole, more courses required research than those did not require research, and that library use increased by course level, except for senior level courses (400 level). Lowry (2012) mapped the competency requirements of the Canadian professional accounting association to ACRL II standards to see if those requirements were being addressed in the curriculum via an accounting syllabus study she conducted in 2011. She found there was a gap, and shared the analysis with faculty and used it as a means of developing course-integrated library instruction. Last, Boss and Drabinski (2014) analyzed business syllabi at Long Island University to identify opportunities for information literacy instruction. They categorized the instructional needs of students into in-depth information literacy (a final integrative project) versus information access skills (access a journal article), and developed instructional strategies for each area.

A few general syllabus studies included business courses, such as the one conducted by Lauer, Merz and Craig (1989), which compared the undergraduate syllabi at two private institutions, Houghton and Aurora Colleges, to see what percent of courses require library use. McGowan, Gonzalez and Stanny (2016) looked at undergraduate syllabi at the University of West Florida to determine which courses had an information literacy learning outcome and some of these included business courses. Smith, Doversberger, Jones, Ladwig, Parker, and Pietraszewski (2012) analyzed syllabi from the University of Notre Dame as a method for developing reaching out to faculty. This study also included some business syllabi.

All of the aforementioned syllabus studies were geared towards uncovering information literacy teaching opportunities, and library service development. They looked for terms such as library, research, and resource (Jeffrey et a., 2017) The McGowan study (2016) categorized information literacy assignments by course level, such as: bibliography, book report or review, case study or class presentation. The Smith study listed multiple ways of incorporating library instruction into a course, such as course pages, mini-instruction sessions, research consultations, and collaboration in creating library assignments. 
The author found these studies useful because they examined which courses could benefit from library instruction. However, none of them addressed data literacy, online or hybrid classes, or discussed the course assignments in detail (other than to say whether it required more or less research). The aims of this study were to add to the understanding of business programs with regards to data literacy, to see whether faculty are including this in their instruction, because current employers are asking for these skills.

\section{This Study: EMU College of Business Syllabus Review for Data Literacy Instructional Opportunities}

Established in 1849, Eastern Michigan University (EMU) in Ypsilanti, Michigan, has approximately 21,000 students. The College of Business, which has AACSB accreditation, enrolls approximately 3,100 students, with 2,500 undergraduate business majors, 740 undergraduate minors, 750 graduate degree students, and 201 graduate certificate students (Eastern Michigan University, 2017).

New faculty at EMU are taught that a syllabus at EMU is a contract between students and a faculty member. It includes the learning objectives, the assignments, as well as the conduct required of all parties (i.e., no sleeping). Since EMU is a public university, syllabi are a matter of public record.

The author spoke with various people about the idea to conduct this study. The Director of the Library directed the author to contact the Associate Dean of the Business School to ask permission. After her agreement, the author contacted department heads in the College of Business and requested their participation. All agreed to participate. In some cases, department employees emailed syllabi to the author. Some printed them out, and in other departments, the collecting process took weeks to complete and was a mix of digital and paper.

During the Fall 2016 semester, 141 syllabi were collected from EMU's College of Business. These included syllabi from graduate and undergraduate classes, as well as in-person, online, and hybrid classes.

Previous syllabus studies, such as Dewald's (2003), applied a five tiered rating scheme to each syllabus:

1. No research or library use

2. Library use for reserve readings

3. Library use for outside readings,

4. Some research or library use for shorter assignments

5. Significant research projects.

Dewald included the word "research" as well as library to incorporate using the somewhat newly available (in 2003) internet resources.

The author used Prado and Marzal's data literacy framework to identify DL teaching opportunities and rate the syllabi. This framework was chosen because it matches more closely with ACRL's information literacy (IL) framework, rather than the DIL skills framework proposed by Carlson, Fossmire, Miller and Nelson. (Shorish, 2015) Also, the data literacy framework is more appropriate to data consumption (rather than the manufacture of data) that business students typically undertake. 
If a class assignment met the upper levels (three or four/five) of the DL framework, the author considered the DL instruction need high-level. If the class assignment met level 1 or 2 of the framework, the DL need is defined as low-level. Figure 1 shows the breakdown of assignments by each level of the framework.

\begin{tabular}{|l|l|l|}
\hline Level & Explanation & $\%$ of total \\
\hline 0 & No need for DL & $77 \%$ \\
\hline 1 & $\begin{array}{l}\text { Understanding what data is, and how it affects society (Given data to work } \\
\text { with) }\end{array}$ & $2 \%$ \\
\hline 2 & Finding or obtaining data (Must search for data) & $7 \%$ \\
\hline $3 / 5$ & $\begin{array}{l}\text { Reading, interpreting and evaluating data (Must search for data and } \\
\text { incorporate it into a report) }\end{array}$ & $12 \%$ \\
\hline \hline
\end{tabular}

Figure 1. Data Literacy Framework

The author conducted this study alone since there are no other business librarians on campus. One of the authors of a previous study (Emily Drabinski) suggested that having one rater would reduce time because there would be no inter-rater conflict. Since the author was looking for broad curricular interventions, and not conducting a scientific analysis, the one person review sufficed. The author went through the syllabi twice, in different orders to ensure sure rating consistency.

\section{THE RESULTS}

The detailed results shown in Figure 2 indicate that overall, IL or DL assignments are required in $62 \%$ of classes. Nine classes have high level needs for both types of literacy, and the author regularly teaches IL in three. The author plans to add DL instruction into those classes and will meet with the faculty members of the remaining six classes to add a library instruction session on DL/IL. 


\begin{tabular}{|c|c|c|c|c|c|c|c|}
\hline $\begin{array}{ll}\text { College } & \text { of } \\
\text { Business } & \\
\text { Department } & \end{array}$ & $\begin{array}{l}\text { Numb } \\
\text { er of } \\
\text { syllabi }\end{array}$ & $\begin{array}{l}\text { \% Low } \\
\text { level } \\
\text { DL } \\
(\text { Level } \\
1+2)\end{array}$ & $\begin{array}{l}\text { \% High } \\
\text { level DL } \\
\text { (Level } 3 \\
+4 / 5)\end{array}$ & $\begin{array}{l}\text { \% Low } \\
\text { level IL } \\
\text { (Level } \\
1+2)\end{array}$ & $\begin{array}{l}\% \text { High } \\
\text { level IL } \\
\text { (Level 3+ } \\
4 / 5)\end{array}$ & $\begin{array}{l}\% \text { IL + } \\
\text { DL High } \\
\text { Level }\end{array}$ & $\begin{array}{lr}\% & \text { No } \\
\text { DL } & \text { or } \\
\text { IL } & \end{array}$ \\
\hline Management & 61 & $3 \%(2)$ & $3 \%(2)$ & $\begin{array}{l}20 \% \\
(12)\end{array}$ & $46 \%(28)$ & $3 \%(2)$ & $\begin{array}{l}31 \% \\
(19)\end{array}$ \\
\hline Marketing & 21 & $14 \%(3)$ & $24 \%(6)$ & $33 \%(7)$ & $38 \%(8)$ & $19 \%(4)$ & $24 \%(5)$ \\
\hline $\begin{array}{l}\text { Finance/Account } \\
\text { ing }\end{array}$ & 33 & $6 \%(2)$ & $\begin{array}{l}30 \% \\
(10)\end{array}$ & $18 \%(6)$ & $12 \%(4)$ & $9 \%(3)$ & $\begin{array}{l}52 \% \\
(17)\end{array}$ \\
\hline $\begin{array}{l}\text { Computer } \\
\text { Information } \\
\text { Science }\end{array}$ & 26 & $23 \%(6)$ & $4 \%(1)$ & $8 \%(2)$ & $15 \%(4)$ & $0 \%(0)$ & $\begin{array}{l}50 \% \\
(13)\end{array}$ \\
\hline Total & 141 & $\begin{array}{l}9 \% \\
(13)\end{array}$ & $\begin{array}{l}13 \% \\
(19)\end{array}$ & $\begin{array}{l}19 \% \\
(27)\end{array}$ & $31 \%(44)$ & $6 \%(9)$ & $\begin{array}{l}38 \% \\
(53)\end{array}$ \\
\hline
\end{tabular}

Figure 2. Detailed Results

Creating a business plan, a document with prescribed sections that is usually used to solicit funding for a new business, is a common business class assignment. Business plans have data literacy requirements because they must include financial data to forecast profit/loss statements, cash flow forecasts, and capital spending plans (McKeever, 2017). They also usually include market data to show the size and anticipated growth rate of the market. Business plans are required in seven courses.

If a class requires low levels of data literacy (levels $1+2$ of the DL framework), the author plans to address instruction with an online tutorial (Boss and Drabinski, 2014). Using tiers of service to segment the instructional need is a necessity because as the only Business librarian, it is not possible for the author to address all instructional needs in a classroom setting. Also, online tutorials can be linked to multiple courses via Research Guides or the Learning Management System. If the class requires high levels of data literacy (levels 3+4/5), the author plans to collaborate with the teaching faculty to design in-class instruction.

\section{Hypothesis Testing}

Hypothesis \#1: Data use in online and hybrid class assignments is greater than for in-person class assignments

The author hypothesized that data use in online classes would be greater than for in-person classes because it seemed that students might be tasked with more research assignments in an online setting in contrast to in-person classes where there is more time for discussion and presentation. This is not the case, as is shown in Figure 3. In-person classes actually require more 
high-level data literacy, though this is not statistically significant, $X^{2}(2, \mathrm{~N}=141)=1.206, \mathrm{p}>.05$. Most in-person classes require group projects which may be cumulative or research-driven. For online and hybrid courses, students are often required to respond as individuals to a community thread or complete shorter assignments. Unlike the kinds of comprehensive projects that complete in-person classes, assignments in online classes tend to be more frequent, shorter, and topicfocused.

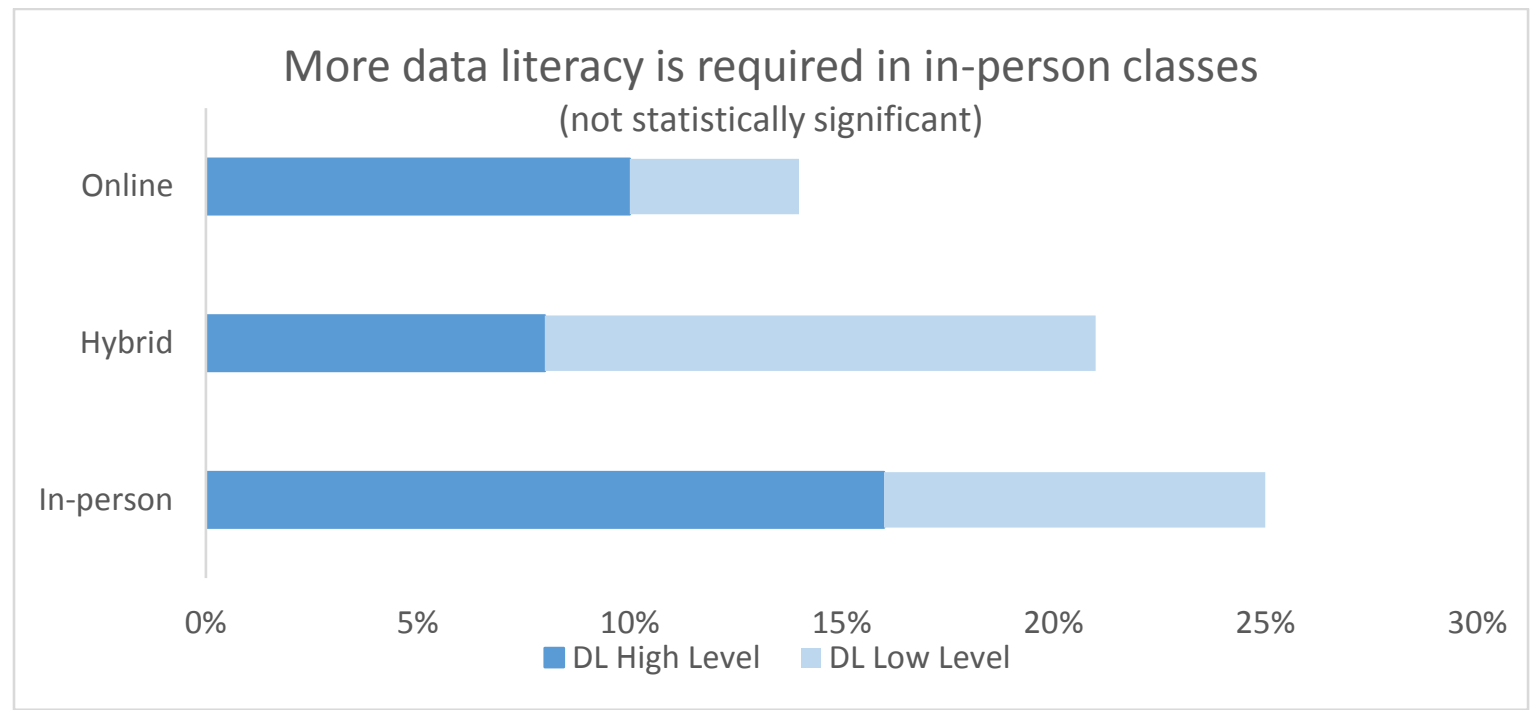

Figure 3. Data Literacy Need by Class Type

Hypothesis \#2: Graduate students have greater data requirements than undergraduate students

Class levels did show differences as demonstrated by previous syllabus surveys (Rambler, 1982; Lauer et al, 1989; Dewald, 2003). The needs for data were somewhat greater in higher level courses, though again these results were not statistically significant, $X^{2}(4, N=141)=4.772, p$ $>.05$. Graduate students have only slightly more need for high level data literacy instruction than undergraduates. See Figure 4, which indicates the data literacy instruction need by course level. Graduate students have greater need for high level data literacy, but when high and low levels are combined, there isn't much difference between graduates and upper level undergraduates. This may be due to the professional, rather than academic, nature of business school. Some courses require consulting with local businesses (real clients), or interviewing career professionals (HR or marketing) to develop a training program, for example. Graduate courses don't appear to require a great deal of data literacy. 


\section{Graduate students have slightly more data needs}

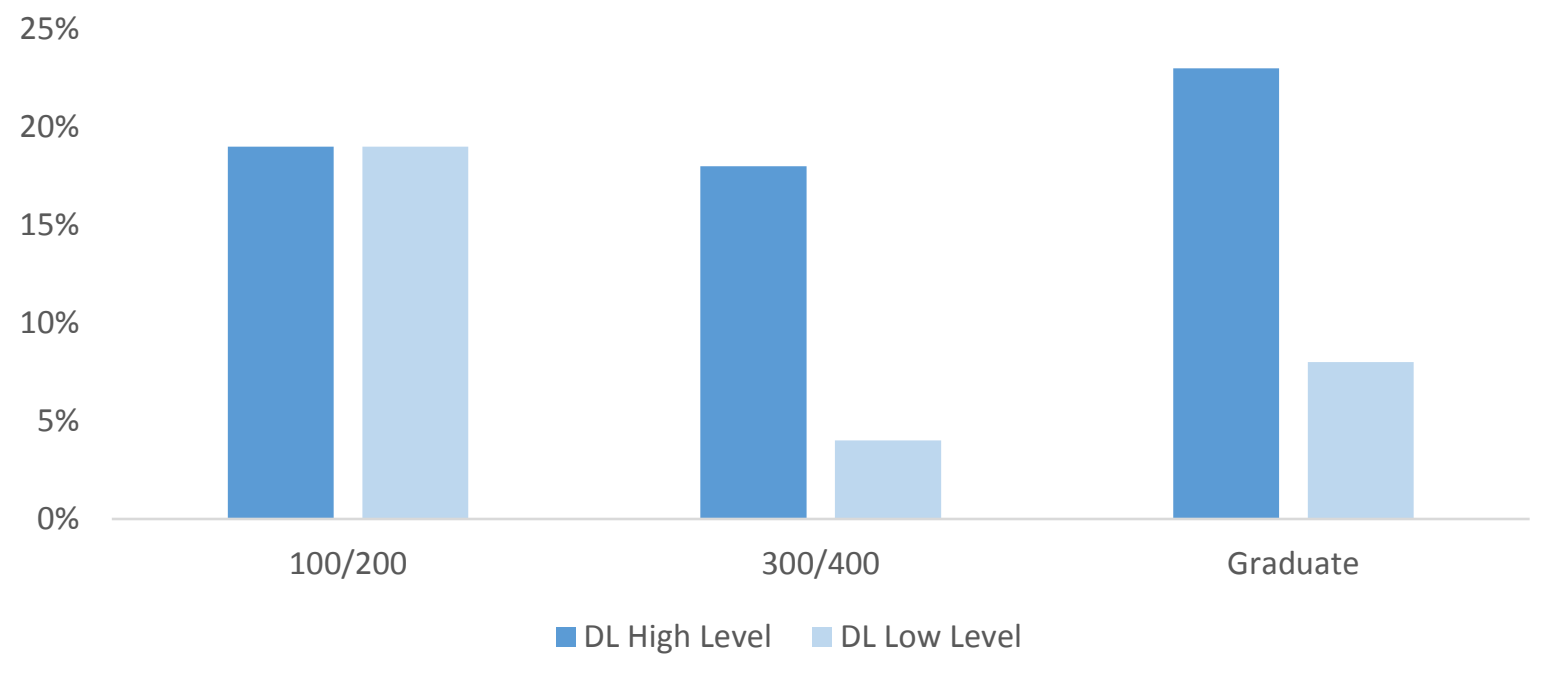

Figure 4. Data Literacy Needs by Course Level

Hypothesis \#3: Different business school disciplines have different data needs (i.e., marketing has more, accounting has less)

It is not surprising that different departments have different data needs because, for example, Computer Information Science is more technical in nature, and Management addresses the skills related to leadership and personnel recruitment. See Figure 5, which shows the DL need by discipline. The author was surprised to find that Finance and Accounting require the most data literacy. Management classes often require students to write papers on issues related to human resources, such as training and employee compensation, and these subjects require little DL. The differences among departments were statistically significant X2 $(4, \mathrm{~N}=141)=29.69, \mathrm{p}<.05$. 


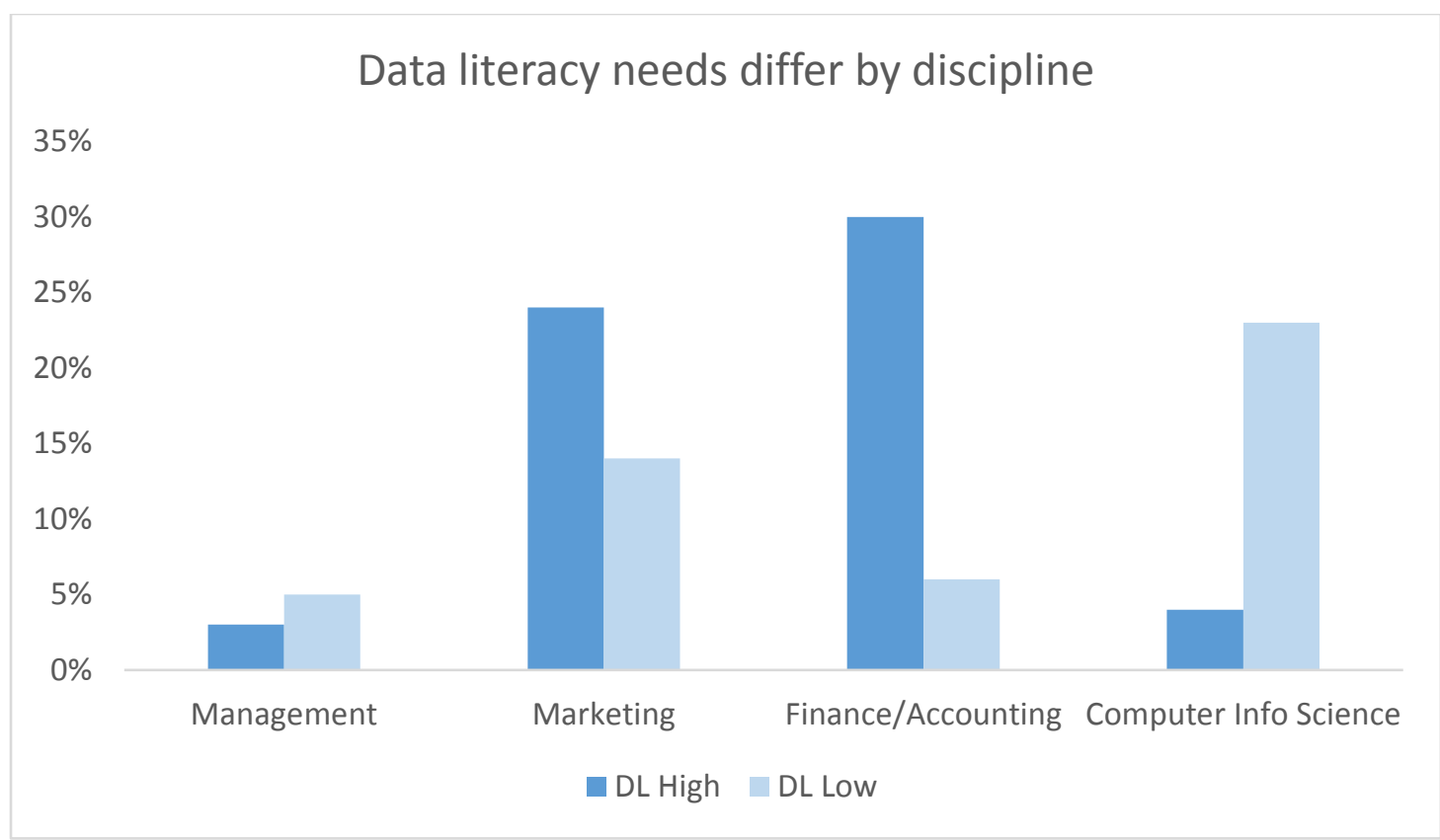

Figure 5. Data Literacy Need by Discipline

\section{Observations}

Like Dewald (2003), the author did not distinguish between research and library use, due to the prevalence of credible business information on the internet. However, the author did note whether the word library was recorded in a syllabus. It was mentioned four times in relation to accessing the Wall Street Journal, and four times to suggest databases for research.

The syllabi indicated several key assignments that could benefit from an online instructional guide. Aside from business plans, another common assignment was case analysis. This was used in 15 classes. Some case analysis assignments had financial components, others were geared towards management issues, and even computer science. Three classes required country reports, which have to do with setting up a business in another country. This topic has economic data considerations such as currency exchange rates, and how to price goods and services in other countries ((Williams et al, 2004).

There was much more information literacy required than the author would have expected. Another round of syllabus review with the intention of detailing information literacy needs would be a useful exercise for determining specific instruction activities.

The syllabus study was a useful technique for a new library liaison to approach and become familiar with the course contents. It will allow targeting courses with specific instructional offerings, rather than sending out blanket emails asking faculty if their students need a session on library or data instruction. It will also give the author enough background information to approach faculty about collaborating on particular course assignments and instruction. 


\section{Information Literacy}

Compared to other business-related syllabus studies, this study showed similar levels of information literacy needs. Figure 6 shows this study found $62 \%$ of classes require information or data literacy, compared with earlier studies which found that somewhere between 38\% and 53\% required some kind of literacy to complete assignments. Given the differences in ratings scales, and colleges or universities, this study is in a similar range as the others.

\begin{tabular}{|l|l|l|}
\hline Study & Department & \% IL/DL required \\
\hline Dewald (2003) & Business Administration & $50 \%$ some or much, 49\% none \\
\hline Lowry (2012) & Accounting (undergraduate) & $38 \%$ some or much, 45\% none \\
\hline Boss \& Drabinski (2015) & Business & $53 \%$ some \\
\hline Brodsky (this study, 2017) & Business & $62 \%$ some, 38\% none \\
\hline
\end{tabular}

Figure 6. Information or Data Literacy Needs in other business syllabus studies

\section{Limitations}

A limitation of all syllabus studies is that they do not capture what faculty say in class, so it is not clear whether or what sort of DL instruction happens in the classroom or online. There were many statements that assignments would be talked about in more detail in class, or that supplemental material would be provided closer to the assignment's due date. It is important to remember that a syllabus is a product of the college classroom experience, but it is not a reflection of the actual teaching or learning outcomes.

This analysis included only one semester's worth of syllabi. It is possible that there are more opportunities for data literacy instruction in classes that are taught at other times of year; or that certain faculty may favor data-oriented assignments, and they teach in different semesters.

The author did not obtain every syllabus from every department. For instance, 21 syllabi were gathered from Marketing, which is probably about a third of the classes that were offered in the fall 2016 semester.

\section{CONCLUSIONS}

Testing of hypothesis \#1 showed that students work with data more in in-person classes than in online or hybrid courses. This is likely due to the group project work required by in-person classes that is less common in online and hybrid classes. The demands for data literacy tend to go up as the course levels get higher. This makes sense as the assignments and group projects become more complex (i.e., reviews of secondary sources and data for company, industry, and market analyses are typical assignments) as shown by hypothesis test \#2. The syllabus review revealed that business students work with data in every department: Marketing, Management, Finance/Accounting, and 
Computer Information Services. Though, according to Hypothesis \#3, data use is highest in Finance/Accounting.

The author collected notes on information literacy requirements while looking for data literacy. Data literacy and information literacy are closely related, in that they both require critical thinking about information sources and uses. The syllabi study revealed that finding and evaluating data sources, figuring out how to incorporate research data into a paper, and tell a cohesive story is a DL skill set that many business classes require. In 2008, VanScoy and Oakleaf concluded that syllabus studies provide librarians with a student-centered approach to integrating library-related instruction into the curriculum. For a liaison librarian, this kind of insight is very valuable, making the syllabus study a useful tool for learning about information and data literacy teaching opportunities, and targeting faculty for outreach.

\section{References}

Boss, K., \& Drabinski, E. (2014). Evidence-based instruction integration: A syllabus analysis project. Reference Services Review, 42(2), 236-276. http://doi.org/10.1108/RSR-07-20130038

Bowerman, B., O'Connell, R., Murphree, E., \& Orris, J. B. (2015). Essentials of business statistics (Irwin Statistics) (5th ed.). New York: McGraw-Hill Education.

Carlson, J., Fossmire, M., Miller, C., \& Nelson, M. S. (2011). Determining data information literacy needs: A study of students and research faculty. portal: Libraries and the Academy, 11(2), 629-657. http://doi.org/10.1353/pla.2011.0022

Dewald, N. H. (2003). Anticipating library use by business students: The uses of a syllabus study. Research Strategies, 19, pp. 33-45. http://doi.org/10.1016/j.resstr.2003.09.003

Eastern Michigan University. (2017). About the College of Business fast facts. Ypsilanti. Retrieved from http://www.emich.edu/cob/about/facts.php

Hargrave, B. (2016, February 1). Do not wait to design programs in data analytics. BizEd Magazine, (AACSB Dean's Conference). Retrieved from http://bized.aacsb.edu/articles/2016/02/do-not-wait-to-design-programs-in-data-analytics

Hart Research Associates. (2015). Falling short? College learning and career success. Association of American Colleges \& Universities. Retrieved from http://www.aacu.org/leap/public-opinion-research/2015-slides

Hogenboom, K., Holler Phillips, C. M., \& Hensley, M. (2011). Show me the data! Partnering with instructors to teach data literacy. ACRL Annual Conference, Philadelphia. Retrieved from http://www.ala.org/acrl/sites/ala.org.acrl/files/content/conferences/confsandpreconfs/nation al/2011/papers/show_me_the_data.pdf 
Jeffrey, K. M., Houk, K. M., Nielsen, J. M., \& Wong-Welch, J. M. (2017). Digging in the mines: Mining course syllabi in search of the library. Evidence Based Library and Information Practice, 12(1). http://dx.doi.org/10.18438/B8GP81

Lauer, J. D., Merz, L. H., \& Craig, S. L. (1989). What syllabi reveal about library use: A comparative look at two private academic institutions. Research Strategies, 7(4), 167-174.

Lowry, L. (2012). Accounting students, library use, and information competence: Evidence from course syllabi and professional accounting association competency maps. Journal of Business \& Finance Librarianship, 17(2), 117-132. http://doi.org/10.1080/08963568.2012.659238

Macy, K. V., \& Coates, H. L. (2016). Data information literacy instruction in business and public health: Comparative case studies. IFLA Journal (Special Issue: Research Data Services), http://doi.org/10.1177/0340035216673382

Maybee, C., Carlson, J., Slebodnik, M., \& Chapman, B. (2015). "It's in the syllabus": Identifying information literacy and data information literacy opportunities using a grounded theory approach. The Journal of Academic Librarianship, 41, 369-376. http://doi.org/10.1016/j.acalib.2016.05.009

McGowan, B., Gonzalez, M., \& Stanny, C. J. (2016, July). What do undergraduate syllabi say about information literacy. portal: Libraries and the Academy, (3), 599-617. http://doi.org/10.1353/pla.2016.0040

McKeever, M. P. (2017). How to write a business plan (13th ed.). Berkeley, CA: NOLO.

Mooney, H., \& Silver, B. (2010, October). Spread the news: Promoting data services. $C \& R L$ News, 480-483.

Prado, J. C., \& Marzal, M. A. (2013). Incorporating data literacy into information literacy programs: Core competencies and contents. Libri, 63(2), 123-134. http://doi.org/10.1515/libri-2013-0010

Rambler, L. K. (1982). Syllabus study: Key to a responsive academic library. The Journal of Academic Librarianship, 8(3), 155-159.

Schield, M. (2013). Reinventing business statistics: Statistical literacy for managers. MBAA Conference. Chicago, IL. Retrieved from http://www.statlit.org/pdf/2013-SchieldMBAA.pdf

Shorish, Y. (2015). Data information literacy and undergraduates: A critical competency. College \& Undergraduate Libraries, 22(1), 97-106. http://doi.org/10.1080/10691316.2015.1001246

Smith, C., Doversberger, L., Jones, S., Ladwig, P., Parker, J., \& Pietraszewski, B. (2012). Using course syllabi to uncover opportunities for curriculum-integrated instruction. Reference \& User Services Quarterly, 51(3), 263-271. 
VanScoy, A., \& Oakleaf, M. J. (2008). Evidence vs. anecdote: Using syllabi to plan curriculumintegrated information literacy instruction. College \& Research Libraries, 69(6), 566-575.

Williams, L. M., Cody, S. A., \& Parnell, J. (2004). Prospecting for new collaborations: Mining syllabi for library service opportunities. The Journal of Academic Librarianship, 30(4), 270-275.

\section{About the author}

Meryl Brodsky is the Business Librarian at Eastern Michigan University in Ypsilanti, MI. 